\title{
Effects of Urban Stormwater-Management Strategies on Stream-Water Quantity and Quality
}

\section{Introduction}

Urbanization results in elevated stormwater runoff, greater and more intense streamflow, and increased delivery of pollutants to local streams and downstream aquatic systems such as the Chesapeake Bay. Stormwater Best Management Practices (BMPs) are used to mitigate these effects of urban land use by retaining large volumes of stormwater runoff (water quantity) and removing pollutants in the runoff (water quality).

\section{What is a BMP?}

Structural stormwater BMPs are constructed in urban areas to mitigate both water-quantity and water-quality issues caused by stormwater runoff (fig. 1). These BMPs can be placed in the stream or on land both above and below the surface. One goal of stormwater BMPs is to detain large volumes of water to prevent urban flooding and erosion of stream channels. Stormwater BMPs used to mitigate these water-quantity issues can include retention ponds, detention ponds, wetlands, infiltration trenches, and underground storage tanks. Another goal of stormwater BMPs is to provide waterquality treatment of stormwater runoff to remove pollutants such as sediment, phosphorus, nitrogen, oils, metals, and trash. Stormwater BMPs providing waterquality treatment can include bioretention cells, wetlands, sand filters for sediment, storm filters for nutrients, and oil and grease separators. Some of these BMPs

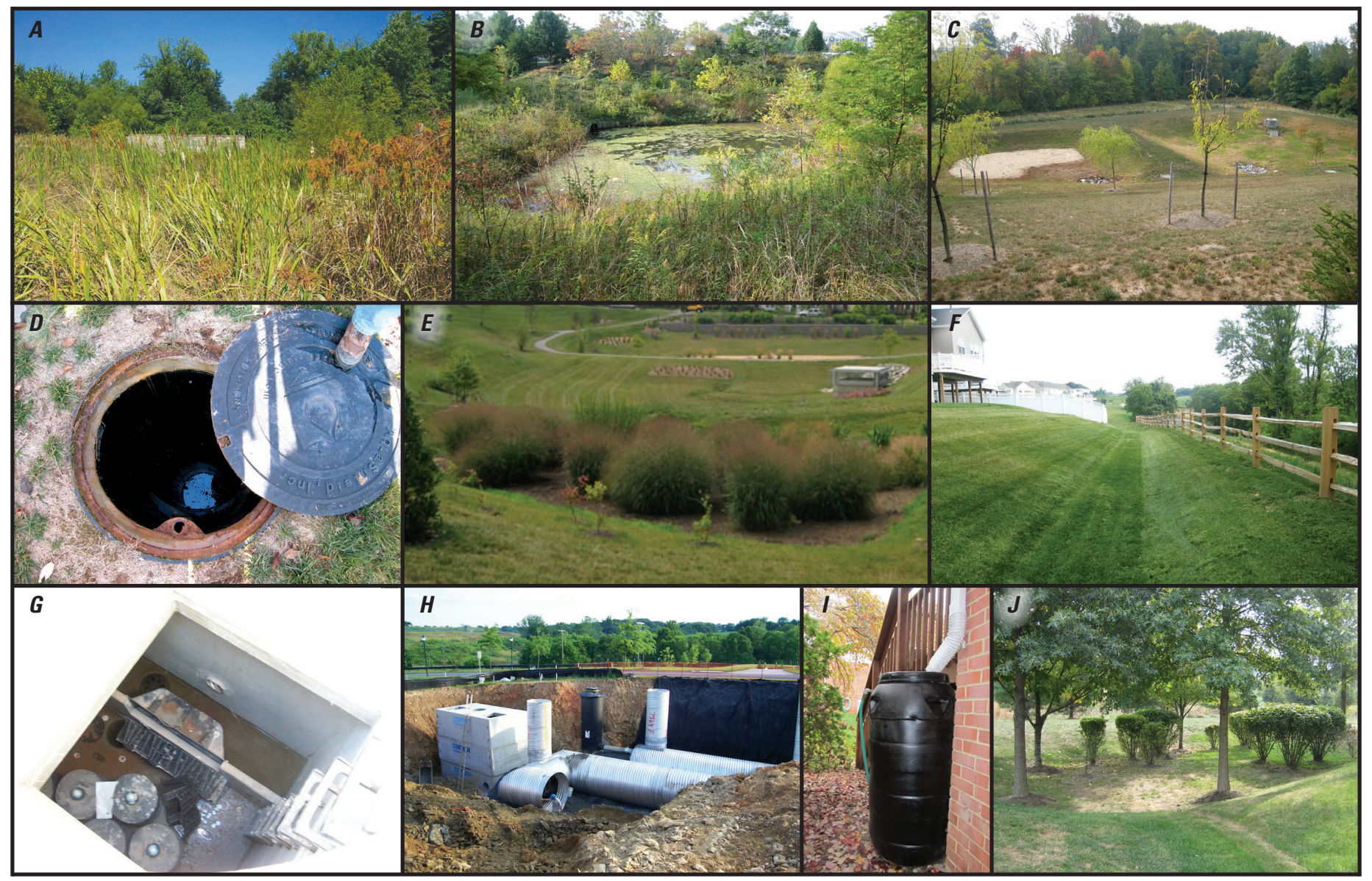

Figure 1. Examples of stormwater Best Management Practices commonly used in urban areas to mitigate stormwater runoff: $(A)$ stormwater wetland, $(B)$ retention (wet) pond, $(C)$ sand filter in series with a detention (dry) pond, $(D)$ oil and grit separator, $(E)$ bioretention cell, $(F)$ grassed swale, $(G)$ underground storm filter, $(H)$ underground detention and filtration units (shown during installation), $(/)$ rain barrel, and $(J)$ rain garden. 
(including wetlands and detention ponds) can provide treatment in both waterquantity and water-quality capacities. In addition to structural BMPs, nonstructural BMPs, such as streetsweeping and public education, are also effectively used to prevent urban pollutants from reaching streams, rivers, and lakes. What remains elusive, however, is knowledge of how the distribution and connectivity (that is, the strategy) of these BMPs in a watershed influences their ability to mitigate large volumes of stormwater runoff and reduce pollutant transport.

\section{Ongoing Research at USGS}

At the U.S. Geological Survey (USGS), researchers in the Eastern Geographic Science Center are studying how the spatial pattern and connectivity of stormwater BMPs affect water quantity and water quality in urban areas. Traditionally, stormwater BMPs have been implemented in a centralized manner with BMPs typically located in the stream channel or directly adjacent to the stream (fig. 2). This is in contrast to recent trends of implementing BMPs on the landscape and in a distributed manner with the goal of treating and retaining stormwater runoff at its source. Research at the USGS is designed to improve understanding of how centralized and
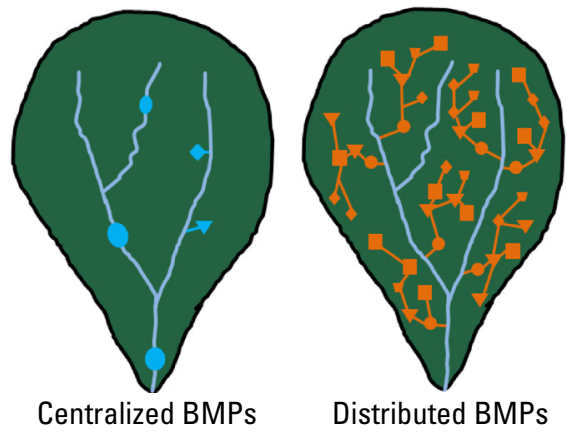

Figure 2. Comparison of contrasting stormwater-management strategies. Centralized Best Management Practices (BMPs) are often located in the stream channel or directly adjacent to the stream, whereas distributed BMPs are dispersed throughout the watershed on the landscape and can provide stormwater treatment in series. Typically, centralized BMPs are designed to treat much larger drainage areas compared to distributed BMPs. Differently shaped distributed BMPs represent the variety of treatment processes shown in figure 1. distributed BMPs differ in their ability to control stormwater and pollutant export from urban watersheds during storm events.

To address this question, monitoring is being conducted in the Clarksburg Special Protection Area in Montgomery County, Maryland, and in the Difficult Run Watershed in Fairfax County, Virginia, in partnership with county, academic, and other Federal agency scientists. Supporting geospatial analyses include land use/land cover (LULC) mapping, topographic feature analyses, and creation of stormwater BMP databases. Field monitoring includes analysis of stream samples collected during storm events, continuous monitoring of streamwater quality using in situ sensors, and monitoring of precipitation.

Data collected as part of this research enables an understanding of how centralized and distributed stormwater BMP strategies and LULC affect watershed hydrology and pollutant transport. For example, stream-discharge data indicate how contrasting stormwater BMP strategies affect the duration of peak discharge during a storm event and the export of water after a storm event occurs (fig. 3). Stream-chemistry and sediment data can reveal how effective these stormwater BMPs are in reducing urban-pollutant export. Detailed and comprehensive LULC, elevation, and BMP databases are essential for understanding and quantifying spatial differences in development patterns and stormwater-management strategy implementation.

\section{Application}

Results from this research provide valuable information to resource managers and regulators on effective ways that stormwater BMPs may be used to mitigate water-quantity and water-quality consequences of urban LULC. Reduction of high-velocity streamflow during storm events by stormwater BMPs could enable more stable streambanks, resulting in less erosion and more robust stream ecology. Identification of effective stormwater-management strategies may help reduce nutrient and pollutant export from urban areas, thereby protecting local streams and downstream systems like the Chesapeake Bay, resulting in healthier and more sustainable aquatic systems.

\section{For additional information, please contact:}

Dianna M. Hogan

U.S. Geological Survey

521 National Center

12201 Sunrise Valley Drive

Reston, VA 20192

Telephone: (703) 648-7240

Email:dhogan@usgs.gov

\section{J.V. Loperfido}

U.S. Geological Survey

521 National Center

12201 Sunrise Valley Drive

Reston, VA 20192

Telephone: (703) 648-5134

Email:jloperfido@usgs.gov

Or visit the USGS Eastern Geographic Science Center at http://egsc.usgs.gov.

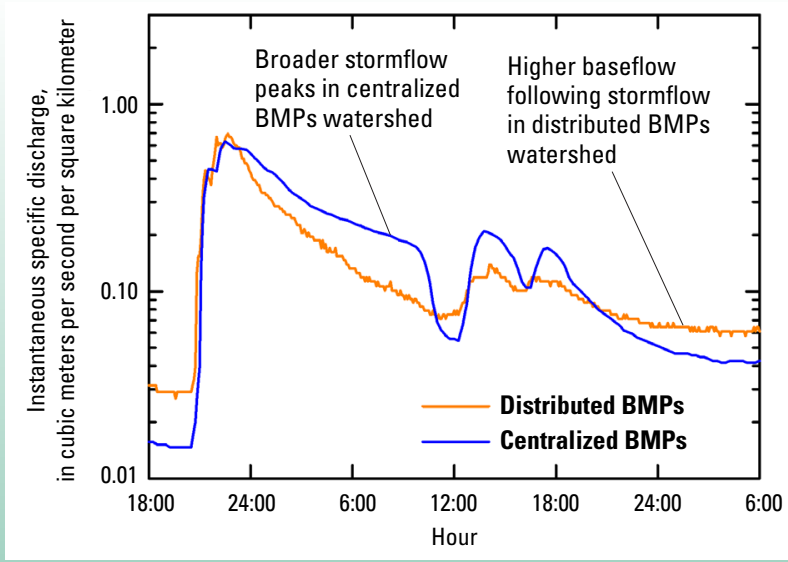

Figure 3. Important differences in stream discharge from watersheds with contrasting stormwater-management strategies include broader peaks during stormflow in the watershed with centralized Best Management Practices (BMPs) and higher stream baseflow following stormflow in the watershed with distributed BMPs (data source http://nwis.waterdata.usgs.gov/nwis). 